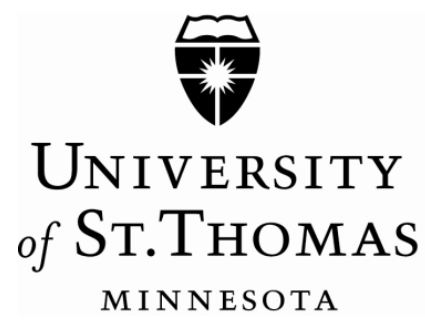

\title{
The Responsiveness of Casino Revenue to the Casino Tax Rate
}

\author{
Kathryn L. Combs, Jim Landers, and John A. Spry \\ Working Paper
}

\begin{abstract}
Copyright (C) 2013 by Kathryn L. Combs, Jim Landers, and John A. Spry. All rights reserved. Do not quote or cite without permission from the authors.

Working papers are in draft form. This working paper is distributed for purposes of comment and discussion only. Its contents should be considered to be preliminary and may not be reproduced without permission of the copyright holder.
\end{abstract}




\title{
THE RESPONSIVENESS OF CASINO REVENUE TO THE CASINO TAX RATE
}

\author{
Kathryn L. Combs, Jim Landers, and John A. Spry*
}

\begin{abstract}
This paper uses variation in Illinois casino taxes to estimate the elasticity of casino adjusted gross receipts (AGR) with respect to the marginal casino tax rate. Illinois' shift to a graduated rate schedule initiated increases in the highest marginal tax rate on AGR from $20 \%$ to $70 \%$ with reversion to a $50 \%$ rate. We construct a state-level casino tax rate variable based on the effective marginal rates on AGR at individual casinos, imputing the tax on casino admissions as a proportion of adjusted gross receipts. We find that a $1 \%$ increase in this casino tax rate decreases AGR by $0.2 \%$.
\end{abstract}

Keywords: gambling, public finance

JEL Codes: L83, H27, H71

Preliminary draft. Please do not cite without permission.

*Combs and Spry: Finance Department, University of St. Thomas, St. Paul/Minneapolis, MN Landers: Indiana Legislative Services Agency, Indianapolis, IN 


\section{INTRODUCTION}

Expansion of the commercial gambling industry in the United States during the 1990s and 2000s has provided a new source of tax revenue for states that have authorized casino gambling. Currently, twenty-two states allow commercial casino operations, defined as land based, riverboat, dockside, and racetrack casinos but not including tribal casinos. ${ }^{1}$ The scope of the gambling industry in the commercial casino states and the tax revenue infusion from casino gambling has been significant. During 2011, 492 casinos operated in the commercial casino states, generating $\$ 35.6$ billion in adjusted gross receipts (AGR) from gambling, and paying $\$ 7.9$ billion in direct casino taxes from their AGR to state governments. ${ }^{2}$ AGR is the "wagering handle" (the total amount wagered by gamblers) minus the "payout" (the amount of winnings paid out to gamblers). ${ }^{3}$ Indeed, revenue production from casino taxes has been an important factor, if not the most important factor, considered by state policy makers when legalizing casino gambling. Concentrated markets in states with a restricted number of licenses can result in rents for the owners of the licenses, which governments may view as an easy source of additional state revenue.

The states that allow commercial casinos to operate also impose specific taxes and special regulations on the casino operators. ${ }^{4}$ Casinos incur these taxes in addition to the prevailing normal sales, income, and real estate taxes imposed by state and local government. As with other state taxes, casino taxes vary substantially among states both in terms of structure and

\footnotetext{
${ }^{1}$ Thirty-seven states have either commercial casinos or tribal casinos or both. See "Types of Gaming by State." American Gaming Association, http://www.americangaming.org/industry-resources/fact-sheets/states-gaming ${ }^{2}$ See "2012 State of the States: The AGA Survey of Casino Entertainment." American Gaming Association, http://www.americangaming.org/industry-resources/research/state-states

${ }^{3}$ AGR is referred to variously as the "takeout", the "house win", or simply the "win". The payout and win also may be measured and discussed as percentages of the wagering handle. These measures are called the "payout rate" and the "win percentage".

${ }^{4}$ John Anderson (2005) gives a comprehensive summary of the regulation and taxation of the casino industry in the United States.
} 
tax burden. Each of the commercial casino states levies a tax on the AGR generated by a casino. The AGR taxes, commonly referred to as wagering taxes, are imposed as a percentage of AGR under both flat rate and graduated rate structures. No matter the structure, the wagering taxes are the dominant revenue producers among state casino taxes. In addition to wagering taxes, several states (all in the Midwest) impose admission taxes equal to a fixed dollar amount per person entering the casino. Like the wagering taxes, admission taxes are also imposed under flat rate and graduated rate structures. Still other states impose machine taxes, which are per-unit taxes on slot machines. As shown in Table 1, the revenue yield in 2011 from direct casino taxes averaged roughly $\$ 0.36$ billion per state in states that have regulated commercial casino gambling. The average yield from gambling taxes is equivalent to the average yield from tobacco taxes and about 45 percent of the average yield from motor fuels taxes in states with casino taxes.

[Table 1 about here]

The levels of casino AGR and the casino direct tax burdens vary widely among commercial casino states, as shown in Table 2. States like Nevada, Mississippi, and New Jersey promote tourism, gambling volume, and employment in the casino sector with relatively low rates of taxation. Gambling in these states is typically associated with destination resort casinos, where hotels, restaurants, and entertainment are found in multiple casinos at a single location, attracting multiple-day visits from tourists. Nevada's casino industry generated the highest casino AGR in 2011, yet was subject to the lowest average tax rate of 8.09 percent. Not coincidentally, Nevada does not restrict the number of casino licenses as do most other states. Other states impose higher wagering tax rates, and many have revised their casino tax schedule upward over time. As of 2011, among the eleven states with highest casino AGR, Pennsylvania 
and New York have the highest average wagering tax rates (48 and 47 percent respectively), followed by Illinois at 33 percent. Considering many states have graduated schedules, the variation in marginal wagering tax rates is even more striking.

[Table 2 about here]

This paper addresses a gap in the literature by estimating the elasticity of casino AGR (and casino admissions) with respect to the direct marginal tax rate on casinos. This is accomplished by exploiting a series of dramatic changes in Illinois' casino tax rates from 1999 to 2006 that amount to a natural policy experiment. During this time period, Illinois' top marginal wagering tax rate rose from 20 to 35 percent, then to 50 percent, then to 70 percent, and finally back to 50 percent, with concurrent adjustments of the top marginal tax rate on admissions. We construct a state-wide casino tax rate variable for Illinois by averaging the effective marginal wagering tax rates faced by each casino, weighted by each casino's AGR. The casino tax rate variable also incorporates an imputation of the admissions tax rates as an equivalent wagering tax. Utilizing monthly data from 1997 through 2008, we find that the elasticity of Illinois' aggregate casino AGR (and admissions) with respect to this casino tax rate is about -0.2 .

\section{LITERATURE}

Research estimating the determinants of gambling comprises literature on lottery games, pari-mutuel horse racing, and casino gambling. A robust literature on lotteries and pari-mutuel horse racing has developed over 30 -plus years. ${ }^{5}$ Within this literature, several studies suggest that the win percentage of lotteries (percent of lottery sales retained by the government) and the win percentage of pari-mutuel horse racing tracks (percent of wagering handle retained by the

\footnotetext{
${ }^{5}$ Grote and Matheson (2011) give a comprehensive summary of the lottery literature.
} 
tracks) is a significant determinant of the amount wagered on lottery games and horse races and by extension the revenue generated by these operations. ${ }^{6}$ In other words, price matters.

A modest body of casino research has analyzed various price and non-price determinants of casino wagering handle and casino AGR. In terms of non-price determinants, Cargill and Eadington (1978) find significant seasonal variation in AGR at Nevada casinos, particularly in the Reno-Sparks and Lake Tahoe markets. Several studies have examined the effects of regulation on casino gambling, including Nichols (1998a, 1998b), Thalheimer and Ali (2003), and Landers (2008). Taken together, these studies find that lifting or reducing boarding/cruising restrictions, wagering loss limits, and restrictions on gaming space have a positive impact on gambling activity. In contrast to a general trend toward deregulation, casino smoking bans have recently been imposed. Studies by Pakko (2006, 2008) and Thalheimer and Ali (2008) find that gambling revenues fell sharply at Delaware racetrack casinos due to that state's smoking ban. Lal and Siahpush (2008) estimate that a smoke-free policy in Victoria, Australia reduced gambling expenditures on electronic gaming machines by approximately 14 percent. Most recently, Garrett and Pakko (2009) estimate more than a 20 percent decline in Illinois casino AGR in 2008 after the Illinois smoking ban was extended to casinos on January 1, 2008. Finally, regarding market structure, Navin and Sullivan (2007) find that entry of new casinos in the St. Louis, Missouri market increased the payout rate to gamblers of slot machines.

One of the shortcomings of this literature on casino gambling is the paucity of estimates of the price elasticity of demand for casino gambling and the absence of estimates of elasticities of

\footnotetext{
${ }^{6}$ Studies on win percentage of pari-mutuel horse betting include Gruen (1976), Suits (1979), and Pescatrice (1980). Studies on win percentage of lotteries include DeBoer (1986), Gulley and Scott (1993), Farrell and Walker (1999), Farrell et al. (2000), Forrest, Gulley, and Simmons (2000), Beenstock and Haitovsky (2001), Yu (2008), and Combs and Spry (2012).
} 
the casino tax base with respect to casino tax rates. ${ }^{7}$ Only two studies (Thalheimer and Ali, 2003; Landers, 2008) estimate the price elasticity of demand for casino gambling. These studies estimate the demand for casino gambling as measured by the slot machine wagering handle, with one of the demand determinants being the win percentage, i.e. the price per dollar gambled. Both studies control for operational, market, and economic factors. Using a sample of casinos operating in Illinois, Indiana, and Iowa, Thalheimer and Ali (2003) estimate that the wagering handle was price-elastic when casino gambling began in these states, but declined to -0.9 by 1997 as the house win percentage declined. Landers (2008) employs a sample of casinos operating in Illinois, Indiana, Iowa, and Missouri from 1991 to 2005. He estimates a long run price elasticity ranging from -0.75 to -0.87 and a short run price elasticity of -0.59 . The short run price elasticity suggests that an adjustment period of more than one year may exist. Ultimately, the price elasticity estimates from both studies are not statistically different from -1.0.

However, price elasticity estimates of casino gambling are inadequate from a public finance perspective. Indeed, the study by Landers (2008) analyzed the decline in wagering handle at Illinois casinos from FY 2002 to FY 2004 after the state's taxes on casinos increased, and found that the average increase in the win percentage was substantially below the levels necessary to fully offset the tax increase. Instead, casinos also reduced operational costs through reductions in customer services, promotional spending, operating hours, $\operatorname{comps}^{8}$, and other strategies in lieu of

\footnotetext{
${ }^{7}$ In contrast, an extremely robust literature has developed over the years analyzing the impact of price changes and tax rate changes on the demand for commodities subject to general sales taxes and special excise taxes like alcohol and tobacco excises. Fujii (1980), Bishop and Yoo (1985), Baltagi and Levin (1986), and Gallet (2007), for instance, estimate the price elasticity of demand for various commodities. More importantly, Friedlaender, Swanson, and Due (1973), Walsh and Jones (1988), Coats (1995), Deskins (2007), Bruce, Deskins and Fox (2008), and Tosun and Skidmore (2012) estimate the tax rate elasticity for the sales tax base and for select excise tax bases. As well, Barzell (1976), Walsh and Jones (1988), Keeler, et al. (1996), Poterba (1996), Besley and Rosen (1999), Young and Bielinska-Kwapisz (2002), and Tosun and Skidmore (2012) estimate the rate at which tax increases are shifted forward to consumers via higher after-tax prices.

${ }^{8}$ Comps are complimentary items and services, such as free gambling chips, drinks, and bus rides, which are given out by casinos to encourage players to gamble.
} 
compensating more fully for the tax increases with increases in the win percentage. This response by Illinois casinos fits with the analysis by Metters, et al. (2008), which illuminates the different components of the casino gambling product and the pricing relating to this product. The overall casino gambling product is comprised of the gambling games plus the various services and amenities offered concurrently by the casino (i.e. bars, restaurants, hotels, spas, other entertainment, and promotional programs that provide free or reduced price access to these amenities). In Illinois, the preponderance of the wagering handle decline potentially was attributable to the operational changes employed by the casinos and not to the changes in the win percentage.

Barzell (1976) examines tax shifting relating to cigarette taxes that is much like the shifting of the casino tax increases that went on in Illinois. He explained the over-shifting of excise taxes into consumer prices as a function of product improvements that may occur in response to the tax increase. He posited that an increase in a per-pack cigarette tax may encourage producers to increase the length of cigarettes. Thus, the price of a pack of cigarettes is increased by more than the tax increase. The price increase is predicated not only on the tax increase but also on the cost of the quality improvement in the cigarettes. Presumably, an alternative strategy could be simply to increase the price to offset part of the tax and then reduce the length of the cigarettes to cut the producer's cost. The price increase and operational cost reduction could offset the additional cost of the tax increase. This appears to have been the strategy of the casinos in Illinois. The win percentage pays for more than just the ability to play the casino's games. It also pays for the package of services, amenities, and promotional programs. Thus, when wagering taxes are increased, the casino can essentially shift the tax forward via a higher win percentage or exact a more implicit price on gamblers by reducing the quality of services, amenities, comps, and other 
promotional programs to cut production costs. In the end, the behavioral response by the Illinois casinos isn't exactly what we would expect of a seller faced with an increase in a sales or excise tax. Therefore, while the price elasticity estimates of Thalheimer and Ali (2003) and Landers (2008) are informative in providing accurate estimates of the response of the casino tax base due to casino tax increases, we need estimates of the tax rate elasticity of AGR.

In summary, previous studies are insufficient in addressing the impact on state budgets from changes in direct casino tax rates. Therefore, this paper's estimation of the tax rate elasticity of AGR (and admissions) provides a more accurate picture for policy makers about the impact of a change in a state's casino tax rates on its casino tax base. In addition, this paper starts to fill a significant gap in the literature on casino taxation, and adds to the broader literature on state and local tax base elasticities.

\section{MIDWESTERN RIVERBOAT GAMBLING}

Riverboat gambling began in Illinois and neighboring Midwestern states in the 1990s, and expanded rapidly at the outset. Illinois legalized riverboat gambling in 1990 and its first casino was open and operating by 1991. The first casinos opened in Iowa, Missouri, and Indiana in 1991, 1994, and 1995, respectively. In addition, Iowa and Wisconsin, which border Illinois, have tribal casinos that are not under the jurisdiction of state gambling regulators.

Currently, riverboat casino gambling in Illinois comprises several oligopolistic or monopolistic geographic markets. The State of Illinois, like its neighbors, controls entry of casinos by issuing a fixed number of licenses at particular geographic locations, on rivers. The market area for each casino typically extends 50 miles, with very few patrons traveling more than 100 miles. Some markets in Illinois span state borders, with multiple casinos operating in the submarkets of (1) Chicago - Northwest Indiana, (2) St. Louis - Southwest Illinois, and (3) 
the Quad Cities area in Illinois and Iowa. Other markets, such as East Peoria, may have only one licensed casino. Figure 1 shows the location of the nine Illinois riverboat casinos and nearby casinos in neighboring states in 2008.

[Figure 1 about here]

Over time, like its neighboring casino states, Illinois has experimented with adjusting its casino regulations in addition to its direct casino tax schedules. For example, cruising requirements were dropped in Illinois as well as in other Midwestern casino states, in an attempt to boost AGR and tax revenues. Illinois has changed its tax schedule several times for both AGR and admissions taxes, although much more frequently and dramatically than Iowa, Indiana, and Missouri. However, Illinois has not lifted its position limit of 1,200 slot machines and table games per casino. Finally, Illinois actually added a restriction when casinos were included in the state smoking ban beginning in January 2008, even though the smoking ban could have a potentially negative effect on gambling AGR and tax revenue.

\section{DATA}

The data for variables directly involved with Illinois casino gambling were obtained from the Illinois Gaming Board. Specifically, monthly adjusted gross receipts data and monthly admissions data for each Illinois casino, monthly state-wide data on numbers of slot machines and table games, and gambling regulatory histories were obtained from the Illinois Gaming Board website. ${ }^{9}$

We chose a sample period for our analysis that ranges from January 1997 through December 2008. All of Illinois' casino tax changes occurred within this sample period. Also, nine casinos had been operating in Illinois for three years by 1997, with no further entry through 2008. The sample period allows for twelve months of data after Illinois' casino smoking ban

\footnotetext{
${ }^{9}$ The Illinois Gaming Board's website is http://www.igb.state.il.us/.
} 
was imposed in January 2008. Finally, our sample period is the same as that used by Garrett and Pakko (2009), which allows us to compare our results to theirs.

Over the sample period, the growth paths of positions, casino AGR, and casino admissions portray a maturing industry with highly seasonal demand patterns. At the beginning of the sample period in 1997 , casinos in Illinois were continuing to expand the size of their operations (up to a position limit of 1,200 slot machines and tables per casino) as reflected in the rapid growth of positions in Figure $1 .^{10}$ Likewise, Figures 2 and 3 depict a rapid initial growth rate of AGR and admissions, which corresponded closely with the introduction of continuous boarding in July 1999. The admissions data is more highly variable than AGR, possibly because any changes in admissions may come from marginal gamblers with lower per capita AGR, as compared with the AGR for the average core casino patron. Over time, the position capacity of the industry was reached, and the growth of AGR and admissions slowed and leveled off. The precipitous drop of AGR and admissions in 2003 coincides with the imposition of the 70 percent top marginal tax rate on AGR in July 2003. AGR and admissions picked up somewhat thereafter until plunging in January 2008 with the beginning of the recession in the United States and the concurrent imposition of the ban on smoking in Illinois casinos.

[Figures 2, 3, and 4 about here]

Illinois has imposed three direct taxes on casinos, beginning with a traditional wagering tax on AGR and an admissions tax. Tables 3 and 4 trace the history of casino taxation in Illinois. Initially, the traditional wagering tax began as a fixed 20 percent of AGR, and was coupled with a tax of $\$ 2$ per admission. Then in 1998, the Illinois legislature passed a bill which was signed by the governor, to implement a graduated AGR tax schedule with rates ranging from 15 to 35

\footnotetext{
${ }^{10}$ One way to increase the number of positions, if the riverboat is at its physical capacity, is to replace the boat with a bigger boat, or bring in a second vessel.
} 
percent. Subsequently, AGR and admissions plateaued until increasing significantly when continuous boarding was allowed in July 1999. However, the next casino tax change did not occur until July 2002, when the graduated AGR tax schedule was expanded to include a top rate of 50 percent, and the admissions tax was increased to a flat rate of $\$ 3$ per admissions. This 2002 change occurred as part of the biennial budget process, to fill in budget gaps from a shortfall of general revenue following the 2001 economic recession. In July 2003, again for budgetary reasons, the wagering tax schedule expanded to a top 70 percent rate on AGR and the admissions tax increased to a graduated tax of $\$ 3$ to $\$ 5$ per admission. ${ }^{11}$ Despite the subsequent increase in casino tax revenue, on July 1, 2005 Illinois returned to the previous graduated rate schedule, with rates on AGR ranging from 15 to 50 percent, but with a stipulation that each casino was responsible through June 2007 for paying the higher of their recent historical AGR tax payment under the previous tax rates or their liability under the new tax schedule. Shortly thereafter, on August 23, 2005, the admissions tax was also scaled back to a graduated schedule with a top rate of $\$ 3$ per admission. ${ }^{12}$

[Tables 3 and 4 about here]

A third tax on Illinois' casinos, enacted in 2006, was essentially a surcharge on casinos earmarked for support to the horse racing industry. The State of Illinois imposed a three percent additional levy on the AGR of four riverboat casinos, specifically those with AGR over \$200 million, from May 26, 2006 until July 11, 2011. The amount collected from this surcharge was

\footnotetext{
${ }^{11}$ Quigley (2003) describes the connection between general budgetary problems and the 2003 change in casino tax rates.

${ }_{12}$ More details on the 2005 changes can be found on the website for the Illinois Legislature's Commission on Government Forecasting (http://www.ilga.gov/commission/cgfa2006/Resource.aspx?id=185), in particular the "Wagering in Illinois 2005 Update", and the April and May 2005 documents on riverboat gaming.
} 
transferred to the Horse Racing Equity Trust Fund, which functions solely as a conduit for funds transfer from the casino industry to horse racing tracks in Illinois. ${ }^{13}$

We take into account the admissions tax rates, as well as the statutory AGR tax rates and the horse racing surcharge on AGR, in constructing the marginal casino tax variable for Illinois. Because Illinois tends to change the wagering tax rates at the same time as the admissions tax rates, it would be incorrect to infer that variation in AGR from tax rate changes is attributable solely to variation in wagering tax. Even though admissions tax revenue is a smaller percentage of casino tax revenue than wagering tax revenue (around 8 percent), ${ }^{14}$ an admissions tax change alone could impact behavior at the margin. For example, it could reduce marketing efforts aimed at seeking marginally profitable gamblers.

To compute the marginal casino tax rate variable for Illinois, we apply a weighted average method to marginal wagering and admissions taxes levied on each of the nine Illinois casinos. Applying the tax rate schedules in Table 3 to the individual casino AGR levels illustrated in Table 5 reveals a wide range of effective tax rates across casinos. Likewise, there is wide variation in admissions and admissions tax rates across casinos. In our computation process, we first impute the marginal admissions tax facing each casino each month as a percent of the casino's AGR by multiplying admissions by the marginal tax per admission and dividing

\footnotetext{
${ }^{13}$ Upon signing the bill that authorized the 3 percent surcharge on casinos in 2006, Governor Blagojevich said, "These bills will help protect the jobs of thousands of hardworking people who depend on the horse racing industry for their livelihood. They will also create a more level playing field that will allow the horse racing industry to remain competitive in Illinois[.]" (Press Release, May 26, 2006, "Governor Blagojevich signs..." http://www3.illinois.gov/PressReleases/ShowPressRelease.cfm?SubjectID=2\&RecNum=4929). Legal actions ensued. First, in 2011, Blagojevich was found guilty of taking a bribe from a race track operator to establish the 3 percent surcharge. However, the fact that a bribe was taken to enact the new tax law did not invalidate the law. Second, in 2012, casinos lost their legal fight against the horseracing surcharge when the law that enacted the tax was upheld in an Illinois state appellate court. Details on these legal actions can be found in Satter (2009); Okon (2011); and CBS Chicago.com, June 27, 2011, "Blagojevich Verdict: the breakdown." http://chicago.cbslocal.com/2011/06/27/blagojevich-verdict-the-breakdown.

${ }_{14}$ Admissions tax revenue was 8.3 percent of the total casino tax revenues in calendar year 2003, with the remainder coming from wagering tax revenue. (2003 Illinois Gaming Board Annual Report, Illinois Gaming Board. http://www.igb.illinois.gov/annualreport/2003igb.pdf )
} 
by total AGR. Next, we add the casino's imputed admissions tax on AGR to the casino's marginal wagering tax on AGR and the casino's horseracing tax on AGR. Finally, we weight this sum of marginal tax rates for each casino by the casino AGR to compute the average of the marginal casino tax rates for the entire state. We refer to this variable as the "casino tax rate." It should be noted that we assume that the "hold harmless" special tax provision from June 2005 through June 2007 (as described at the end of Table 3) did not affect casino decision making at the margin, and so we do not incorporate this provision into the computation of the casino tax rate. $^{15}$

[Table 5 about here]

The resulting casino tax rate monthly series is displayed in Figure 5. This tax rate starts at about 25 percent at the beginning of the sample period, peaks at 61 percent in 2003 , and falls back to around 50 percent beginning in 2005 . The statutory changes in the tax regimes can clearly be seen, with the change to the graduated wagering tax in 1998, the increase in the top rate in 2002 and again in 2003, and the 2005 reversion to the earlier rates. The surcharge on AGR to support horse racing tracks has a small but noticeable impact on the casino tax rate beginning with its implementation in 2006. Table 6 presents summary statistics for the casino tax rate as well as Illinois casino AGR, admissions, number of positions, and the Philadelphia Federal Reserve Bank's Economic Activity Index for Illinois.

[Figure 5 and Table 6 about here]

\footnotetext{
${ }^{15}$ Under the hold harmless provision, each casino was liable for the maximum of the computed wagering tax (according to the new graduated schedule of 2005) or a flat, guarantee amount for its preceding fiscal year. Guarantee amounts were set based on the casino's previous AGR history, and are listed at the end of Table 3. All but two casinos ended up being subject to the guarantee amounts from July 2005 through June 2006, and all but three from July 2006 through June 2007. Theoretically, it is hard to determine if the wagering tax would be viewed as a zero percent marginal rate by a casino for which the guarantee amount is binding. A casino's perceived marginal tax rate in would depend in part its projections of AGR, which would be highly dependent on macroeconomic effects. For these reasons, we do not take into account the "hold harmless" provision in this study, although it may be appropriate to explore the provision in a study of individual casinos.
} 


\section{ECONOMETRIC MODEL}

The model for statewide AGR and for statewide admissions is specified as

$$
\ln \left(y_{t}\right)=\beta_{0}+\beta_{1} \ln \left(\text { casino tax rate } \text { cas }_{t}+\boldsymbol{\beta}_{2}^{\prime} \boldsymbol{X}_{\boldsymbol{t}}+\beta_{3} \ln \left(y_{t-1}\right)+\varepsilon_{t}\right.
$$

where $y_{t}$ is Illinois' monthly AGR or monthly admissions. We assume an AR(1) process due to serial correlation of the monthly data. Standard errors are calculated using the Newey-West adjustment procedure for heteroskadasticity/autocorrelation. The vector $\boldsymbol{X}_{\boldsymbol{t}}$ includes dummy variables for regulatory changes in Illinois, the positions variable, trend and business cycle variables, and seasonal dummy variables. We interpret the coefficient of the log of the casino tax rate as a short-run elasticity. Illinois limits the number of casinos and the number of positions at each casino, which greatly restricts long run entry and expansion. This likely acts as a binding constraint for Illinois casinos. In contrast to the 1,200 position constraint for each Illinois casino, Indiana's Blue Chip Casino replaced its smaller riverboat in 2006 with an 85,000 square foot riverboat housing 2,221 gaming positions. As a result, the Blue Chip Casino experienced a pronounced, large increase in AGR. ${ }^{16}$ In addition, although theoretically casinos are free to exit, none choose to exit the Illinois casino oligopoly. However, one possible long run adjustment to higher marginal tax rates that our model does not consider is reduced investment in complementary goods and services, like golf courses. ${ }^{17}$

The model specification assumes that the casino tax rate is an exogenous determinant of both AGR and admissions. Although casino tax rate changes are not pure random events, they

\footnotetext{
${ }^{16}$ See Inside INdiana Business, January 31, 2006, "Blue Chip Casino Opens New Boat in Michigan City." http://www.insideindianabusiness.com/newsitem.asp?ID=16653

${ }^{17}$ One disadvantage of highly graduated income tax schedules is that they create a disincentive for those individuals facing the highest rates to earn income that would expand the size of the tax base. Similarly, a state imposing high tax rates on its casinos creates a disincentive for them to make capital investments. In Illinois, the number of positions is capped, but not other capital investments. With a marginal tax rate of 70 percent on adjusted gross revenue, if a casino's entertainment portfolio (hotels, spas, restaurants, entertainment, golf courses, etc.) is expanded to bring in $\$ 1,000$ additional adjusted gross receipts, the casino keeps less than $\$ 300$ of that increase because all the additional expenses have to be paid out of the $\$ 300$.
} 
appear to be disconnected from month-to-month changes in the growth path of casino tax revenues. As described above, statutory shifts in the tax schedule occur at discrete intervals that are timed with respect to various political factors like the biennial budget cycle and often influenced by shortfalls in other revenue sources rather than shortfalls in casino tax revenue.

Garrett and Pakko (2009) use a similar model with the exception of the casino tax rate series. Like them, we also control for continuous boarding and the smoking ban, the two notable regulatory changes in our sample period. As discussed above, both of these regulatory changes have been shown to be important determinants of the demand for casino gambling. We use a dummy variable for the change in Illinois gaming regulation which permitted continuous boarding beginning in July 1999. With this change, Illinois discontinued the requirement that a riverboat needed to pull away from its dock while gaming took place. The Continuous Boarding variable takes a value of zero prior to July 1999, and a value of one thereafter. The Smokefree variable used in the model controls for the Illinois casino smoking ban effective January 2008. Smokefree takes a value of zero prior to January 2008 and one otherwise. With regard to the casino tax rate, Garrett and Pakko (2009) employ a dummy variable for the highest AGR tax rate from July 2003 through June 2005, so they are unable to estimate the elasticity of the tax base with respect to the tax rate. They also control for snowfall; we were unable to obtain snowfall data.

Our model accounts for supply-side changes. Following Nichols and Tosun (2008), we include the number of slot machines and gaming tables, although we use a single "positions" monthly variable by summing the number of slots and tables rather than including these measures as separate variables. 
Additional variables are included to account for industry growth, macroeconomic fluctuation, and seasonal fluctuation. Trend and squared trend variables account for the initial rapid growth and subsequent maturation of the market. To control for the macroeconomic business cycle, we use the monthly Coincident Economic Activity Index data for Illinois, obtained from the Federal Reserve Bank of Philadelphia. The high degree of seasonal fluctuation in AGR and Admissions is captured by means of eleven monthly dummy variables, with January as the omitted month.

We do not control for regulatory changes in other states. Although such changes may have cross-border impacts in geographical submarkets, it is unlikely that regulatory changes in a neighboring state will have a noticeable impact on state-level AGR or admissions in Illinois. Nevertheless, we did perform regressions, not reported here, that controlled for the 1999 and 2003 changes to continuous boarding in Missouri and Indiana, respectively. However, these variables were not statistically significant in explaining variation in either AGR or admissions in Illinois. This is not inconsistent with the finding in Garrett and Pakko (2009) that the smoking ban in Illinois did not have a statistically significant effect on statewide levels of AGR or admissions in the neighboring states of Indiana, Iowa, or Missouri, even though its effect in Illinois was quite large.

\section{RESULTS}

We estimate Models 1 through 3 for AGR and Models 1 through 3 for Admissions. In each case, Model 1 omits the positions variable, Model 2 includes positions, and Model 3 includes the log of positions.

Beginning with the AGR estimates as shown in Table 7, we find that AGR is inelastic with respect to the casino tax rate. The coefficients of the log of the tax rate variable range from - 
0.220 to -0.235 and are highly statistically significant. That is, a one percent increase in the casino tax rate causes an estimated decrease in AGR of approximately two tenths of one percent. ${ }^{18}$ The increase in unit tax revenue is not offset fully by a reduction in tax revenues; therefore, a casino tax rate increase results in higher casino tax revenue.

[Table 7 about here]

In addition, the regulatory changes have large, highly statistically significant influences on AGR. The smoking ban variable coefficient estimates range from -0.191 to -0.194 . That is, the smoking ban is responsible for between a 17 to 18 percent decrease in AGR. ${ }^{19}$ Our estimate compares to a somewhat larger estimate of a 22 percent decrease in AGR found by Garrett and Pakko (2009). The coefficients of Continuous Boarding range from 0.183 to 0.194. That is, continuous boarding boosts AGR by an estimated 20 to 21 percent. $^{20}$

Most of the growth and seasonal control variables are statistically significant. The quadratic trend term estimates show that AGR increases with time but at a diminishing rate, all else constant. However, neither of the position variable coefficient estimates is statistically significant. It is possible that much of the growth of industry capacity may already be captured by the quadratic trend. AGR is pro-cyclical according to the estimated positive coefficient of the economic activity index. Finally, the monthly dummy coefficients display a great deal of seasonal variation, although the estimates of these coefficients are not reported here.

Turning to the determinants of admissions, the tax elasticity and other estimates for the admissions models are shown in Table 8. Similar to the AGR results, the elasticity of admissions with respect to the casino tax rate is highly statistically significant and is estimated to be between

\footnotetext{
18 Garrett and Pakko (2009) find that their tax dummy variable (corresponding to the forty percent increase in the top marginal wagering tax rate from July 2003 to June 2005) has an estimated 12 percent negative impact on monthly AGR.

${ }^{19}$ With a log dependent variable, the coefficient, b, of a right hand side dummy variable should be interpreted as the proportional effect on the dependent variable of $\exp (\mathrm{b})-1$.

${ }^{20}$ Garrett and Pakko (2009) estimate a 23 percent positive impact from continuous boarding.
} 
-0.226 and -0.234 . That is, a one percent increase in the casino tax rate leads to a decrease of about two-tenths of one percent in the monthly admissions count. ${ }^{21}$

[Table 8 about here]

Casino regulatory policy has a somewhat mixed effect on admissions. The coefficient of the continuous boarding variable is positive and highly statistically significant, ranging from 0.301 to 0.305 . That is, there is a remarkable increase in the monthly admissions counts of 35 to 36 percent that is attributable to the shift to continuous boarding. However, unlike Garrett and Pakko (2009), and in contrast with the AGR results, our estimated coefficient of the smoking ban for admissions is not a statistically significant determinant of admissions. ${ }^{22}$ Perhaps the discrepancy is attributable to some specification differences between the models. In addition, the admissions series is extremely variable. Admissions data is also subject to an interesting form of measurement error. ${ }^{23}$ In the end, even if the smoking ban doesn't impact admissions, our results suggest that it may decrease smokers' rates of gambling, as they now need to take breaks to smoke outside the casino rather than smoke while they gamble on the gaming floor.

The growth path variables do not have a strong effect on admissions, although the monthly dummy coefficient estimates show significant seasonality. In all three admissions models, the trend variable is not statistically significant, although the trend squared estimates are statistically significant but small and negative. Therefore the quadratic trend accounts for a

\footnotetext{
${ }^{21}$ Garrett and Pakko (2009) find that their tax dummy variable (corresponding to the forty percent increase in the top marginal wagering tax rate from July 2003 to June 2005) has an estimated 18 percent negative impact on monthly admissions.

${ }^{22}$ Garrett and Pakko (2009) find that continuous boarding has a slightly lower estimated impact of 31.2 percent increase in admissions. However, they estimate a 12.3 percent decrease in admissions due to the smoking ban. Nevertheless, their estimates do concur with our finding that, in general, the smoking ban impacts casino AGR much more than the number of admissions.

${ }^{23}$ According to a government report, "some gaming experts have indicated that when admission taxes were raised in FY 2004, some casinos relocated their admission turnstiles to make sure they were only counting those patrons who were entering the casino to gamble....and to better keep under-age visitors from entering." State of Illinois, Commission on Government Forecasting and Accountability, Wagering in Illinois: 2006 Update (p. 11). http://www.ilga.gov/commission/cgfa2006/Upload/2006wagering_in_illinois.pdf
} 
slight decline in admissions over time. The coefficients of the positions variables are not statistically significant. Similar to the AGR models, though, admissions are found to be procyclical. Finally, the estimates of each monthly dummy coefficient are larger across the board than the corresponding coefficient estimates for each of the AGR models.

\section{A. Robustness Checks}

Because the variables in this study are levels, not differences, some of the right hand side variables are correlated with one another. In particular we were concerned about the high correlations of the log of the tax variable with the trend variable, and of the economic activity index with the trend variable. To see whether these correlations impacted our results, we ran alternative regression models for AGR, none of which proved to be superior to our original specifications in Table 7.

We estimated several alternative models. First we performed a single-variable regression of the log of AGR against the log of the tax variable. This regression produced a positive tax elasticity, which indicates the necessity of controlling for other factors. Next, we ran the full scale version of Model 3, omitting each of the following right hand side variables, one at a time: trend, square of trend, log of tax variable, log of positions, economic activity index, Smokefree, continuous boarding, and the monthly dummy variables. We compared our results from each of the variable elimination experiments to the results in Table 7. Eliminating the economic activity index had little effect on the tax elasticity but produced a negative coefficient of the log of positions. Eliminating the trend variable (and in separate regressions, trend squared and the Smokefree variable) reduced the statistical significance of the estimated tax elasticity to well below 90 percent, and substantially reduced its magnitude. Eliminating continuous boarding had little effect on the estimated coefficients of the remaining variables, with the exception of the log 
of positions, which became statistically significant at the 95 percent confidence level. Similarly, eliminating the monthly dummy variables had little effect on the estimated coefficients, but slightly reduced the R-squared statistic.

\section{CONCLUSION}

This paper contributes to the literature on gambling by providing the first estimate, to our knowledge, of the elasticity of the casino tax base with respect to marginal casino tax rates. The methodology uses Illinois' casino tax rate changes as a natural experiment where the highest marginal rate on the largest casinos' adjusted gross receipts fluctuates from 20 to 70 percent during our 144-month sample period. We find an inelastic response of state-level casino adjusted gross receipts to a state-level measure of the direct casino marginal tax rate in Illinois; hence, casino tax revenue tends to rise when the marginal casino tax rate is increased, all else constant. Some caution should be used in interpreting the estimates of Illinois' tax elasticities. They should be viewed as short run elasticities. Illinois' gaming position limits of 1,200 slot machines and table games per casino may result in lower tax elasticities than otherwise because entry is restricted and casinos are restricted in their abilities to increase their gaming capacity. Other states' casino tax bases may show differing responses to increases in direct casino tax rates. Casinos in states without position limits may have other ways to respond to tax changes, such as increasing the size of their boat and the number of positions if tax rates decrease. Therefore our elasticity estimates are conditional on a regulatory environment with binding position limits. However, Illinois may still experience some long run adjustment of casino investment in amenities like hotels and golf courses, in response to casino tax changes, which may additionally affect the tax base. 
Future research that examines the effects of taxation on AGR and admissions on individual casinos may be informative, for Illinois and other states as well. Panel or other methods that can identify the degree of local casino competition and cross-border effects could shed light on variability of the casino tax elasticity across different geographical areas within and across states.

\section{ACKNOWLEDGMENTS}

We would like to thank Victor Matheson and participants in the session on Topics in the Economics of Gambling at the 2009 Western Economic Association International Conference, and Mehmet Tosun and participants in the Four Cases in Revenue Estimation and Forecasting session at the 2010 National Tax Association Conference for their comments on an earlier version of this paper. All errors are our own. The views expressed herein are those of the authors and not necessarily those of any governmental agency. 


\section{REFERENCES}

Anderson, John E., 2005. "Casino Taxation in the United States." National Tax Journal 58(2), 303-324.

Baltagi, Badi H., and Dan Levin, 1986. "Estimating Dynamic Demand for Cigarettes Using Panel Data: The Effects of Bootlegging, Taxation and Advertising Reconsidered." The Review of Economics and Statistics 68(1), 148-155.

Barzel, Yoram, 1976. "An Alternative Approach to the Analysis of Taxation." Journal of Political Economy 84(6), 1177-1197.

Beenstock, Michael and Yoel Haitovsky, 2001. "Lottomania and Other Anomalies in the Market for Lotto." Journal of Economic Psychology 22(6), 721-744.

Besley, Timothy J., and Harvey S. Rosen, 1999. "Sales Taxes and Prices: An Empirical Analysis." National Tax Journal 52(2), 157-178.

Bishop, John A., and Jang H. Yoo, 1985. "“Health Scare,' Excise Taxes and Advertising Ban in the Cigarette Demand and Supply." Southern Economic Journal 52(2), 402-411.

Bruce, Donald, John Deskins, and William Fox, 2008. "On the Relative Distortions of State Sales and Corporate Income Taxes.” Working Paper. Creighton University, Omaha, NE.

Cargill, Thomas F., and William R. Eadington, 1978. "Nevada's Gaming Revenues: Time Characteristics and Forecasting." Management Science 24(12), 1221-1230.

Coats, R. Morris, 1995. "A Note on Estimating Cross-Border Effects of State Cigarette Taxes." National Tax Journal 48(4), 573-584.

Combs, Kathryn L. and John A. Spry, 2012. "Who Plays the Numbers Games in the Middle of the Day?" Applied Economics 44(7), 889-897.

DeBoer, Larry, 1986. "Lottery Taxes May Be Too High.” Journal of Policy Analysis and Management 5(3), 594-596.

Deskins, John, 2007. “Are Tax Policy Distortions Increasing?” Unpublished paper. College of Business Administration, Creighton University: Omaha, NE.

Farrell, Lisa, and Ian Walker, 1999. "The Welfare Effects of Lotto: Evidence from the UK." Journal of Public Economics 72(1), 99-120.

Farrell, Lisa, Roger Hartley, Gauthier Lanot, and Ian Walker, 2000. "The Demand for Lotto: The Role of Conscious Selection.” Journal of Business \& Economic Statistics 18(2), 228-142.

Forrest, David, O. David Gulley, and Robert Simmons, 2000. "Elasticity of Demand for U.K. National Lottery Tickets." National Tax Journal 53(4), 853-863. 
Friedlander, Ann F., Gerald J. Swanson, and John Due, 1973. "Estimating Sales Tax Revenue Changes in Response to Changes in Personal Income and Sales Tax Rates." National Tax Journal 26(1), 103-110.

Fujii, Edwin T., 1980. “The Demand for Cigarettes: Further Empirical Evidence and Its Implications for Public Policy.” Applied Economics 12(4), 479-489.

Gallet, Craig A., 2007. "The Demand for Alcohol: A Meta-Analysis of Elasticities.” The Australian Journal of Agricultural and Resource Economics 51(2), 121-135.

Garrett, Thomas A., and Michael R. Pakko, 2009. "Casino Revenue and the Illinois Smoking Ban.” Working Paper 2009-027A. Federal Reserve Bank of St. Louis, St. Louis, MO.

Grote, Kent R., and Victor A. Matheson, 2011. "The Economics of Lotteries: A Survey of the Literature." Faculty Research Series, Paper No. 11-09. College of the Holy Cross, Worcester, MA.

Gruen, Arthur, 1976. “An Inquiry into the Economics of Race-Track Gambling.” Journal of Political Economy 84(1), 169-177.

Gulley, O. David, and Frank A. Scott, Jr., 1993. "The Demand for Wagering on State-Operated Lotto Games." National Tax Journal 46(1), 13-22.

Keeler, Theodore E., The-Wei Hu, Paul G. Barnett, Willard G. Manning, and Hai-Yen Sung, 1996. "Do Cigarette Producers Price-discriminate by State? An Empirical Analysis of Local Cigarette Pricing and Taxation." Journal of Health Economics 15(4), 499-512.

Lal, A., and M. Siahpush, 2008. "The Effect of Smoke-Free Policies on Electronic Gaming Machine Expenditure in Victoria, Australia." Journal of Epidemiology and Community Health 62(1), 11-15.

Landers, Jim, 2008. "What's the Potential Impact of Casino Tax Increases on Wagering Handle: Estimates of the Price Elasticity of Demand for Casino Gaming." Economics Bulletin 8(6), 1-15.

Metters, Richard, Carrie Queenan, Mark Ferguson, Laura Harrison, Jon Higbie, Stan Ward, Bruce Barfield, Tammy Farley, H. Ahmet Kuyumcu, and Amar Duggasani, 2008. "The 'Killer Application' of Revenue Management: Harrah's Cherokee Casino \& Hotel.” Interfaces 38(3), 161-175.

Navin, John C., and Timothy S. Sullivan, 2007. "Do Riverboat Casinos Act as Competitors? A Look at the St. Louis Market." Economic Development Quarterly 21(1), 49-59.

Nichols, Mark. W., 1998a. "Deregulation and Cross-Border Substitution in Iowa's Riverboat Gambling Industry.” Journal of Gambling Studies 14 (2), 151-172. 
Nichols, Mark. W., 1998b. "The Impact of Deregulation on Casino Win in Atlantic City." Review of Industrial Organization 13(6), 713-726.

Nichols, Mark W., and Mehmet S. Tosun, 2008. "The Income Elasticity of Gross Casino Revenues: Short-Run and Long-Run Estimates.” National Tax Journal 61(4), 635-652.

Okon, Bob, 2011. "Casinos Lose Again in Tax Fight." Joliet Herald News February 9, http://heraldnews.suntimes.com/news/3733949-418/casinos-lose-again-in-tax-fight.html.

Pakko, M. R., 2006. "Smoke-Free Law Did Affect Revenue from Gaming in Delaware.” Tobacco Control 15(1), 68-69.

Pakko, Michael R., 2008. "No Smoking at the Slot Machines: The Effect of a Smoke-Free Law on Delaware Gaming Revenues." Applied Economics 40(14), 1769-1774.

Pescatrice, Donn R., 1980. “The Inelastic Demand for Wagering.” Applied Economics 12(1), 110.

Poterba, James M., 1996. "Retail Price Reactions to Changes in State and Local Sales Taxes." National Tax Journal 49(2), 165-176.

Quigley, Kelly, 2003. “Gaming Tax too Severe: Report.” Crain's Chicago Business March 20, http://www.chicagobusiness.com/section/news\&date=20130320.

Satter, Raphael G., 2009. "Casinos Sue Blagojevich Over Horse Track Law." The America's Intelligence Wire, June 13.

Suits, Daniel B., 1979. “The Elasticity of Demand for Gambling.” The Quarterly Journal of Economics 93(1): 155-162.

Thalheimer, Richard, and Mukhtar M. Ali, 2003. "The Demand for Casino Gaming." Applied Economics 35(7), 907-918.

Thalheimer, Richard, and Mukhtar M. Ali, 2008. "The Demand for Casino Gaming with Special Reference to a Smoking Ban.” Applied Economics 46(2), 273-282.

Tosun, Mehmet S., and Mark L. Skidmore, 2012. "Cross-Border Shopping and the Sales Tax: An Examination of Food Purchases in West Virginia." The B.E. Journal of Economic Analysis \& Policy 7(1).

Walsh, Michael J., and Jonathan D. Jones, 1988. "More Evidence on the 'Border Tax' Effect: The Case of West Virginia, 1979-84.” National Tax Journal 41(2), 261-265.

Young, Douglas J., and Angnieska Bielinksa-Kwapisz, 2002. "Alcohol Taxes and Beverage Prices." National Tax Journal 55(1), 57-73. 
$\mathrm{Yu}$, Kam, 2008. "Measuring the Output and Prices of the Lottery Sector: An Application of Implicit Expected Utility Theory." NBER Working Papers, No. 14020. Cambridge, MA. 


\section{Table 1}

Comparison of Casino Tax Revenue and Other State Revenue Sources (2011)

\begin{tabular}{lccc}
\hline \multicolumn{1}{c}{ Type of Tax } & $\begin{array}{c}\text { Amount } \\
\text { (\$billion) }\end{array}$ & $\begin{array}{c}\text { Number of States } \\
\text { With Tax }\end{array}$ & $\begin{array}{c}\text { Average Amount in } \\
\text { States With Tax } \\
\text { (\$billion) }\end{array}$ \\
\hline Casino Taxes $^{1}$ & 7.92 & 22 & 0.36 \\
Individual Income Tax & 259.14 & 43 & 6.03 \\
General Sales Tax & 234.48 & 45 & 5.21 \\
Corporate Income Tax & 40.20 & 46 & 0.87 \\
Motor Fuels Tax & 39.89 & 50 & 0.80 \\
Tobacco Products Tax & 17.25 & 50 & 0.35 \\
Insurance Premiums Tax & 16.42 & 50 & 0.33 \\
Alcoholic Beverage Tax & 5.73 & 50 & 0.11 \\
Death and Gift Taxes & 4.49 & 40 & 0.11 \\
\hline
\end{tabular}

(1) Casino taxes include taxes on casinos and racetrack casinos.

Sources: (i) American Gaming Association. 2012 State of the States: The AGA Survey of Casino Entertainment. http://www.americangaming.org/industry-resources/research/state-states. (ii) U.S. Census Bureau, State Government Tax Collections - 2009. http://www.census.gov/govs/statetax/. 
Table 2

State Casino Adjusted Gross Receipts and Tax Revenue (2011)

\begin{tabular}{lrrr}
\hline \multicolumn{1}{c}{ State } & $\begin{array}{c}\text { Casino Adjusted } \\
\text { Gross Receipts } \\
\text { (\$millions) }\end{array}$ & $\begin{array}{c}\text { Casino Tax } \\
\text { Revenue } \\
\text { (\$millions) }\end{array}$ & $\begin{array}{c}\text { Average Tax Rate } \\
(\%)\end{array}$ \\
\hline States with Highest Adjusted Gross Receipts & 10,700 & 865.3 & 8.09 \\
Nevada & 3,320 & 277.6 & 48.21 \\
New Jersey & 3,020 & $1,456.0$ & 31.12 \\
Pennsylvania & 2,720 & 846.4 & 24.19 \\
Indiana & 2,370 & 573.2 & 12.25 \\
Louisiana & 2,240 & 274.4 & 26.79 \\
Mississippi & 1,810 & 484.8 & 33.07 \\
Missouri & 1,480 & 489.4 & 22.64 \\
Illinois & 1,420 & 321.5 & 22.58 \\
Iowa & 1,420 & 320.7 & 47.10 \\
Michigan & 1,260 & 593.4 & \\
New York & 31,760 & $6,502.7$ & \\
Subtotal & 3,880 & $1,427.3$ & \\
Remaining 11 States & 35,640 & $7,930.0$ & \\
Grand Total & & & \\
\hline
\end{tabular}

Source: American Gaming Association. 2012 State of the States: The AGA Survey of Casino Entertainment. http://www.americangaming.org/industry-resources/research/state-states 


\begin{tabular}{|c|c|c|}
\hline \multicolumn{3}{|c|}{$\begin{array}{c}\text { Table } 3 \\
\text { Illinois Casino Wagering Tax Schedules fro }\end{array}$} \\
\hline Year & $\begin{array}{l}\text { Calendar Year Adjusted Gross } \\
\text { Receipts Increment (\$million) }\end{array}$ & Tax Rate (\%) \\
\hline Start to $12-31-97$ & All & 20 \\
\hline $1-1-98$ to $6-30-02$ & $\begin{array}{l}0-25 \\
25-50 \\
50-75 \\
75-100 \\
\text { Over } 100\end{array}$ & $\begin{array}{l}15 \\
20 \\
25 \\
30 \\
35\end{array}$ \\
\hline $7-1-02$ to $6-30-03$ & $\begin{array}{l}0-25 \\
25-50 \\
50-75 \\
75-100 \\
100-150 \\
150-200 \\
\text { Over } 200\end{array}$ & $\begin{array}{l}15.0 \\
22.5 \\
27.5 \\
32.5 \\
37.5 \\
45.0 \\
50.0\end{array}$ \\
\hline $7-1-03$ to $6-30-05$ & $\begin{array}{l}0-25 \\
25-37.5 \\
37.5-50 \\
50-75 \\
75-100 \\
100-250 \\
\text { Over 250 }\end{array}$ & $\begin{array}{l}15.0 \\
27.5 \\
32.5 \\
37.5 \\
45.0 \\
50.0 \\
70.0\end{array}$ \\
\hline $7-1-05$ to Present ${ }^{1,2}$ & $\begin{array}{l}0-25 \\
25-50 \\
50-75 \\
75-100 \\
100-150 \\
150-200 \\
\text { Over 200 }\end{array}$ & $\begin{array}{l}15.0 \\
22.5 \\
27.5 \\
32.5 \\
37.5 \\
45.0 \\
50.0\end{array}$ \\
\hline
\end{tabular}

Notes: (1) From 7-1-05 to 6-30-07, each casino pays the maximum of: (i) the computed wagering tax; or (ii) the guarantee amount below.

\begin{tabular}{ll}
\hline \multicolumn{1}{c}{ Riverboat } & Guaranteed Amount (\$million) \\
\hline Alton & 31 \\
E. Peoria & 43 \\
Joliet-Empress & 86 \\
Metropolis & 45 \\
Joliet-Harrah's & 114 \\
Aurora & 86 \\
E. St. Louis & 48.5 \\
Elgin & 198 \\
\hline
\end{tabular}

(2) From 5-26-06 to 7-11-11, casinos with yearly AGR of \$200 M or more pay an additional 3 percent of AGR into the Horse Racing Equity Trust Fund.

Sources: (i) Illinois Gaming Board, 2012 Annual Report, p. 17. http://www.igb.illinois.gov. (ii) State of Illinois, Commission on Government Forecasting and Accountability, Wagering in Illinois: 2006 Update (pp. 5-7).

http://www.ilga.gov/commission/cgfa2006/Upload/2006wagering_in_illinois.pdf 


\section{Table 4}

Illinois Casino Admission Tax Schedules from Start to Present

\begin{tabular}{lcc} 
Year & $\begin{array}{c}\text { Number of Admissions in } \\
\text { Prior Calendar Year } \\
\text { (million) }\end{array}$ & Tax per Admission (\$) \\
\hline Start to 6-30-02 & All & 2 \\
7-1-02 to 6-30-03 & All & 3 \\
& & 3 \\
$7-1-03$ to 8-23-05 & $0-1$ & 4 \\
& $1-2.3$ & 5 \\
Over 2.3 & 2 \\
8-23-05 to Present & $0-1$ & 3 \\
& Over 1 & \\
\hline
\end{tabular}

Sources: (i) Illinois Gaming Board, 2012 Annual Report, p. 17. http://www.igb.illinois.gov (ii) State of Illinois, Commission on Government Forecasting and Accountability, Wagering in Illinois: 2006 Update (pp. 5-7). http://www.ilga.gov/commission/cgfa2006/Upload/2006wagering_in_illinois.pdf 
Table 5

Illinois Casino Adjusted Gross Receipts in 2004

\begin{tabular}{lc}
\hline \multicolumn{1}{c}{ Casino } & $\begin{array}{c}\text { Adjusted Gross } \\
\text { Receipts (\$million) }\end{array}$ \\
\hline Alton & 107.3 \\
Aurora & 229.5 \\
East St. Louis & 166.3 \\
East Peoria & 132.6 \\
Elgin & 400.5 \\
Joliet Empress & 228.1 \\
Joliet Harrah's & 272.3 \\
Metropolis & 142.9 \\
Rock Island & 38.4 \\
\hline
\end{tabular}

Source: Illinois Gaming Board, 2004 Illinois Gaming Board Annual Report, p. 14. http://www.igb.illinois.gov/ 


\section{Table 6}

Descriptive Statistics

\begin{tabular}{lrrrrr}
\hline & $\begin{array}{c}\text { Adjusted Gross } \\
\text { Receipts } \\
\text { (\$million) }\end{array}$ & $\begin{array}{c}\text { Number of } \\
\text { Admissions }\end{array}$ & $\begin{array}{c}\text { Casino Tax } \\
\text { Rate }\end{array}$ & $\begin{array}{c}\text { Number of } \\
\text { Positions }\end{array}$ & $\begin{array}{c}\text { Economic } \\
\text { Activity Index } \\
\text { for Illinois }\end{array}$ \\
\hline Mean & 135.420 & $1,347,639$ & 0.4510 & $9,573.78$ & 142.17 \\
Median & 143.084 & $1,318,749$ & 0.4925 & 9,926 & 141.87 \\
Maximum & 184.206 & $1,783,223$ & 0.6140 & 10,487 & 154.39 \\
Minimum & 80.604 & 961,745 & 0.2463 & 8,342 & 124.10 \\
Standard Deviation & 25.344 & $192,164.3$ & 0.1064 & 663.61 & 7.33 \\
\hline Observations & 144 & 144 & 144 & 144 & 144 \\
\hline
\end{tabular}

Note: Monthly data from January 1997 through December 2008. 


\section{Table 7}

Estimates of the Impact of the Casino Tax Rate (log) on Casino Adjusted Gross Receipts (log)

\begin{tabular}{|c|c|c|c|}
\hline & (1) & (2) & (3) \\
\hline Constant & $\begin{array}{c}16.273 * * * \\
(0.218)\end{array}$ & $\begin{array}{c}15.973 * * * \\
(0.291)\end{array}$ & $\begin{array}{c}13.141 * * * \\
(2.769)\end{array}$ \\
\hline $\log ($ Casino Tax Rate $)$ & $\begin{array}{c}-0.235 * * * \\
(0.047)\end{array}$ & $\begin{array}{c}-0.222 * * * \\
(0.052)\end{array}$ & $\begin{array}{c}-0.220 * * * \\
(0.052)\end{array}$ \\
\hline Smokefree & $\begin{array}{c}-0.194 * * * \\
(0.020)\end{array}$ & $\begin{array}{c}-0.191 * * * \\
(0.020)\end{array}$ & $\begin{array}{c}-0.192 * * * \\
(0.020)\end{array}$ \\
\hline Continuous Boarding & $\begin{array}{c}0.194 * * * \\
(0.022)\end{array}$ & $\begin{array}{c}0.184 * * * \\
(0.016)\end{array}$ & $\begin{array}{c}0.183 * * * \\
(0.016)\end{array}$ \\
\hline Economic Activity Index & $\begin{array}{c}0.006 * * * \\
(0.001)\end{array}$ & $\begin{array}{c}0.007 * * * \\
(0.002)\end{array}$ & $\begin{array}{c}0.007 * * * \\
(0.002)\end{array}$ \\
\hline Positions & & $\begin{array}{c}3.48 \mathrm{E}-05 \\
(3.43 \mathrm{E}-05)\end{array}$ & \\
\hline Log(Positions) & & & $\begin{array}{c}0.347 \\
(0.314)\end{array}$ \\
\hline Trend & $\begin{array}{c}0.015^{* * * *} \\
(0.002)\end{array}$ & $\begin{array}{c}0.013 * * * \\
(0.003)\end{array}$ & $\begin{array}{c}0.013 * * * \\
(0.003)\end{array}$ \\
\hline Trend Squared & $\begin{array}{c}-4.32 \mathrm{E}-05 * * * \\
(7.09 \mathrm{E}-06)\end{array}$ & $\begin{array}{c}-3.90 \mathrm{E}-05^{* * *} \\
(8.98 \mathrm{E}-06)\end{array}$ & $\begin{array}{c}-3.85 \mathrm{E}-05 * * * \\
(8.98 \mathrm{E}-06)\end{array}$ \\
\hline $\mathrm{AR}(1)$ & $\begin{array}{c}0.283 * * * \\
(0.102)\end{array}$ & $\begin{array}{c}0.267 * * * \\
(0.098)\end{array}$ & $\begin{array}{c}0.265 * * * \\
(0.097)\end{array}$ \\
\hline Observations & 144 & 144 & 144 \\
\hline R-squared & 0.976 & 0.977 & 0.977 \\
\hline Adjusted R-squared & 0.973 & 0.973 & 0.973 \\
\hline F-statistic & 287.2 & 272.7 & 273.1 \\
\hline Durbin-Watson statistic & 2.03 & 2.00 & 1.99 \\
\hline
\end{tabular}

Notes: Asterisks denote significance at the $1 \%(* * *), 5 \%(* *)$, and $10 \%(*)$ levels. Newey-West standard errors are in parentheses. Dummy variables to correct for seasonal monthly effects were included for eleven months, but coefficients are not reported here. 


\section{Table 8}

Estimates of the Impact of the Casino Tax Rate (log) on Casino Admissions (log)

\begin{tabular}{|c|c|c|c|}
\hline & (1) & (2) & (3) \\
\hline Constant & $\begin{array}{c}12.268 * * * \\
(0.280)\end{array}$ & $\begin{array}{c}12.404 * * * \\
(0.548)\end{array}$ & $\begin{array}{c}13.670 * * * \\
(4.310)\end{array}$ \\
\hline $\log ($ Casino Tax Rate $)$ & $\begin{array}{c}-0.226 * * * \\
(0.062)\end{array}$ & $\begin{array}{c}-0.233 * * * \\
(0.072)\end{array}$ & $\begin{array}{c}-0.234 * * * \\
(0.072)\end{array}$ \\
\hline Smokefree & $\begin{array}{l}-0.029 \\
(0.029)\end{array}$ & $\begin{array}{l}-0.030 \\
(0.030)\end{array}$ & $\begin{array}{l}-0.030 \\
(0.030)\end{array}$ \\
\hline Continuous Boarding & $\begin{array}{c}0.301 * * * \\
(0.024)\end{array}$ & $\begin{array}{c}0.305^{* * *} \\
(0.022)\end{array}$ & $\begin{array}{c}0.305^{* * *} \\
(0.022)\end{array}$ \\
\hline Economic Activity Index & $\begin{array}{c}0.008 * * * \\
(0.002)\end{array}$ & $\begin{array}{c}0.008 * * \\
(0.003)\end{array}$ & $\begin{array}{c}0.007 * * \\
(0.003)\end{array}$ \\
\hline Positions & & $\begin{array}{l}-1.56 \mathrm{E}-05 \\
(5.10 \mathrm{E}-05)\end{array}$ & \\
\hline Log(Positions $)$ & & & $\begin{array}{l}-0.155 \\
(0.472)\end{array}$ \\
\hline Trend & $\begin{array}{c}0.005 \\
(0.003)\end{array}$ & $\begin{array}{c}0.006 \\
(0.005)\end{array}$ & $\begin{array}{c}0.006 \\
(0.005)\end{array}$ \\
\hline Trend Squared & $\begin{array}{c}-2.45 \mathrm{E}-05^{* *} \\
(1.06 \mathrm{E}-05)\end{array}$ & $\begin{array}{c}-2.64 \mathrm{E}-05^{* *} \\
(1.32 \mathrm{E}-05)\end{array}$ & $\begin{array}{c}-2.66 \mathrm{E}-05^{* *} \\
(1.33 \mathrm{E}-05)\end{array}$ \\
\hline $\operatorname{AR}(1)$ & $\begin{array}{c}0.206 \\
(0.160)\end{array}$ & $\begin{array}{c}0.207 \\
(0.159)\end{array}$ & $\begin{array}{c}0.207 \\
(0.159)\end{array}$ \\
\hline Observations & 144 & 144 & 144 \\
\hline R-squared & 0.905 & 0.905 & 0.905 \\
\hline Adjusted R-squared & 0.892 & 0.891 & 0.891 \\
\hline F-statistic & 66.4 & 62.5 & 62.5 \\
\hline Durbin-Watson statistic & 1.33 & 1.34 & 1.34 \\
\hline
\end{tabular}

Notes: Asterisks denote significance and the $1 \%(* * *), 5 \%(* *)$, and $10 \%(*)$ levels. Newey-West standard errors are in parentheses. Dummy variables to correct for seasonal monthly effects were included for eleven months, but coefficients are not reported here. 
Figure 1

Map of Riverboat Casinos in Illinois and Neighboring States

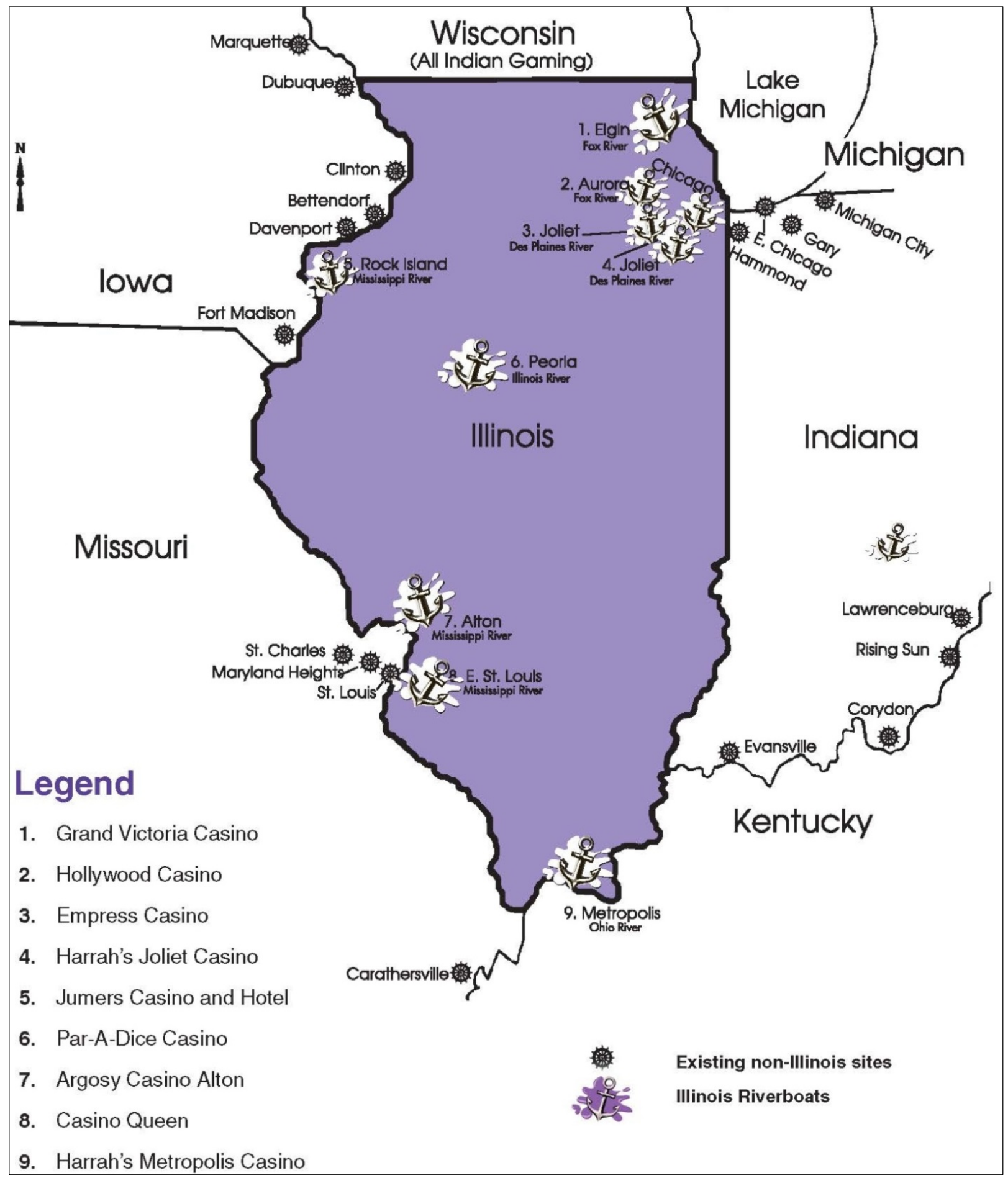

Source: Illinois Gaming Board, 2008 Illinois Gaming Board Annual Report, p. 20.

http://www.igb.illinois.gov/annualreport/2008igb.pdf 
Figure 2

Number of Positions in Illinois Casinos by Month

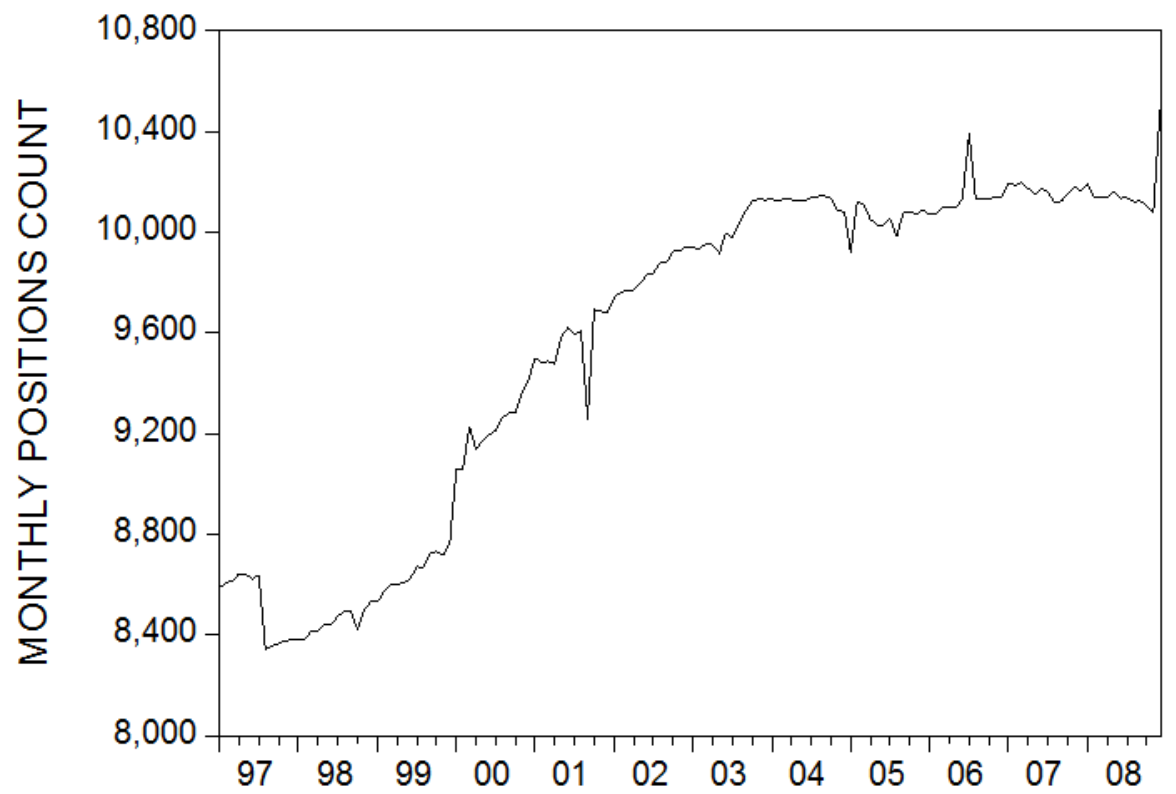


Figure 3

Illinois Casino Adjusted Gross Receipts by Month

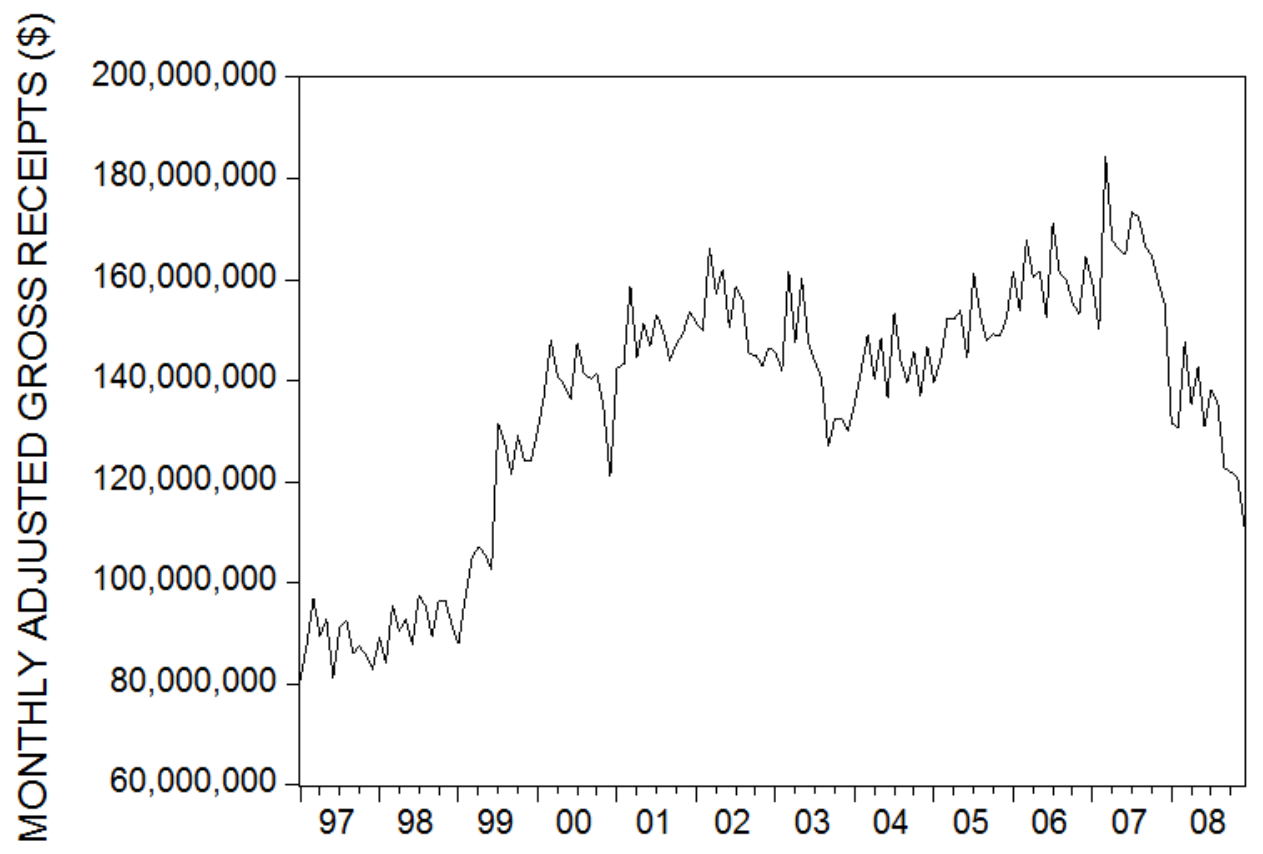


Figure 4

Illinois Casino Admissions by Month

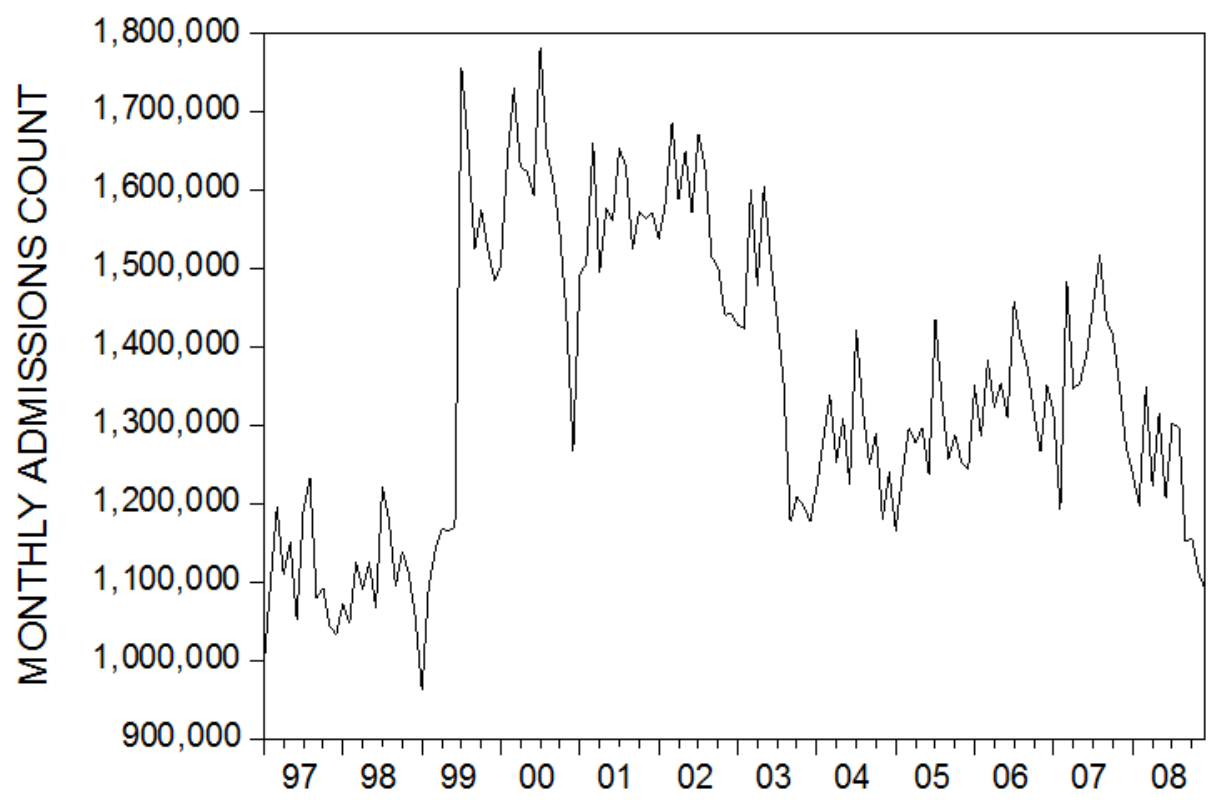


Figure 5

Illinois Casino Tax Rate Variable by Month

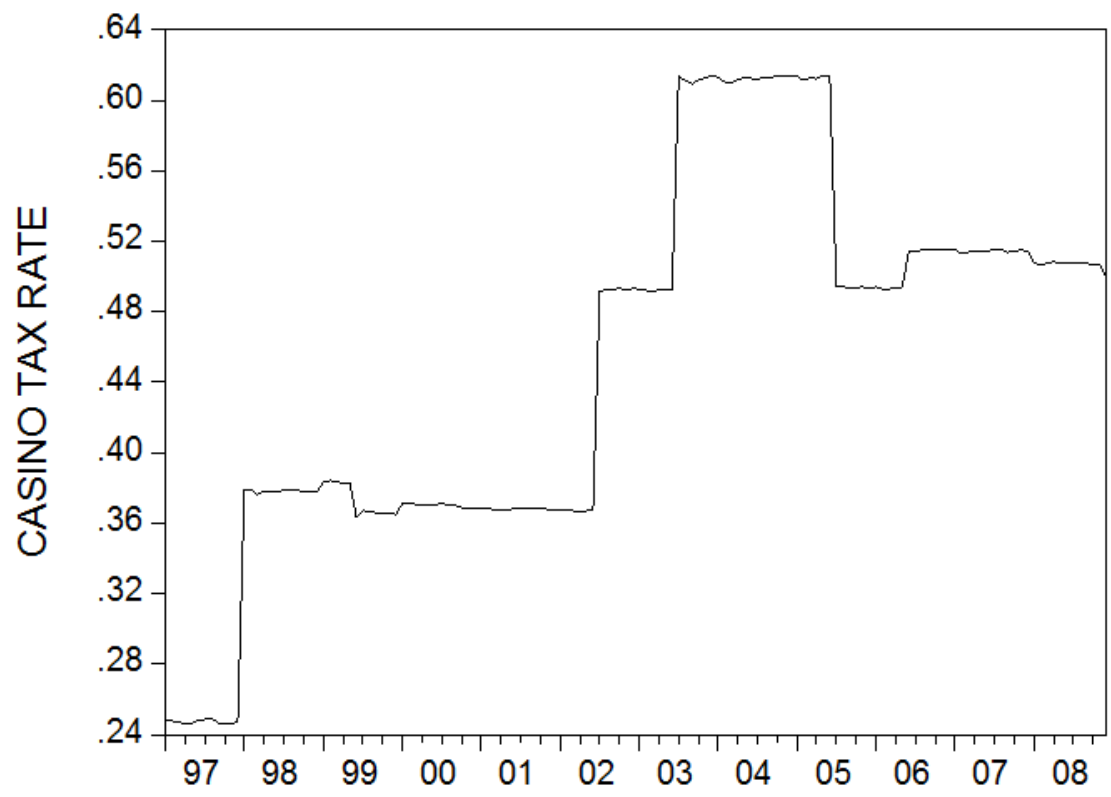

